\title{
THE PREVALENCE OF PHYSICAL AND PSYCHOLOGICAL ABUSE AND ITS CORRELATION WITH DEPRESSIVE AND ANXIETY SYMPTOMS AMONG STUDENTS
}

Ivana Simic Vukomanovic ${ }^{1}$, Sanja Kocic ${ }^{1,2}$, Svetlana Radevic ${ }^{2}$, Snezana Radovanovic ${ }^{1}$, Dragan Vasiljevic ${ }^{1,2}$,

Vladimir Djordjevic ${ }^{3}$ and Slavica Djukic Dejanovic ${ }^{2,3}$

${ }^{1}$ Institute of Public Health Kragujevac, Serbia

${ }^{2}$ Faculty of Medical Sciences, University of Kragujevac, Serbia

${ }^{3}$ Clinic for Psychiatry "Laza Lazarevic", Belgrade, Serbia

\section{PREVALENCIJA FIZIČKO G I PSIHIČKOG ZLOSTAVLJANJA I NJENA POVEZANOST SA NASTANKOM}

\author{
DEPRESIVNOSTI I ANKSIOZNOSTI KOD STUDENTSKE POPULACIJE \\ Ivana Simic Vukomanovic ${ }^{1}$, Sanja Kocic ${ }^{1,2}$, Svetlana Radevic ${ }^{2}$, Snezana Radovanovic ${ }^{1}$, Dragan Vasiljevic ${ }^{1,2}$, \\ Vladimir Djordjevic ${ }^{3}$ i Slavica Djukic Dejanovic ${ }^{2,3}$. \\ ${ }^{1}$ Institut za javno zdravlje Kragujevac, Srbija \\ ${ }^{2}$ Fakultet medicinskih nauka, Univerzitet u Kragujevcu, Srbija \\ ${ }^{3}$ Clinic for Psychiatry “Laza Lazarevic", Belgrade, Serbia
}

Received / Primljen: 03. 06. 2016.

Accepted / Prihvaćen: 07. 07. 2016.

\begin{abstract}
Abuse in younger populations has been an issue of growing concern globally since youth already face various life situations that can heighten the occurrence of depression and anxiety disorders. The aim of this study was to determine the prevalence of physical and psychological abuse and its correlation with depressive and anxiety symptoms among students.

This research was conducted as an epidemiological study of a sample of 1,940 university students using a standardized questionnaire by the World Health Organization. The survey, in addition to questions related to the abuse of youth, also included the Beck Depression Inventory and Beck Anxiety Inventory.

Based on the results of this study, psychological abuse had a prevalence of $17.1 \%$, while the prevalence of physical abuse was approximately $1.8 \%$. Depressive symptoms were significantly related to physical $(p<0.001)$ and psychological abuse $(p<0.005)$, and anxiety symptoms were also significantly related to both physical $(p=0.003)$ and psychological abuse ( $p<0.005)$.

The results of this study indicated the importance of the early detection of abuse and depressive and anxiety symptoms among university students, which is essential for mental health promotion and the prevention of mental disorders.
\end{abstract}

Keywords: University students, depressive symptoms, anxiety symptoms, physical abuse, psychological abuse.

\section{SAŽETAK}

Zlostavljanje kod populacije mladih, postaje sve više sfera interesovanja na globalnom nivou, jer sučeljavanje sa brojnim životnim situacijama koje nosi ovaj period života ubrzava nastanak depresivnih i anksioznih poremećaja. Cilj našeg istraživanja je da se utvrdi prevalencija fizičkog i psihičkog zlostavljanja, i njena povezanost sa nastankom depresivnosti $i$ anksioznosti kod ispitivane studentske populacije.

Istraživanje je sprovedeno kao epidemiološka studija preseka na uzorku od 1940 studenata, korišćenjem standardizovanog upitnika Svetske zdravstvene organizacije koji je pored aspekta vezanog za zlostavljanjene kod mladih, obuhvatao Bekovu skalu za procenu depresivnosti i Bekovu skalu za procenu anksioznosti.

Na ispitivanom uzorku studenata, prevalencija psihičkog zlostavljanja iznosi $17,1 \%$ a prevalencija fizičkog zlostavljanja 1,8\%. Utvrdeno je da postoji povezanost između nastanka depresivnih simptoma sa fizičkim zlostavljanjem $(p<0,001)$ kao $i$ psihičkim zlostavljanjem $(p<0,005)$. U pogledu anksioznih simptoma, takodje je nadjena povezanost kako sa fizičkim zlostavljanjem $(p<0,003)$ tako i sa psihičkim zlostavljanjem $(p<0,005)$.

Dobijeni rezultati ukazuju na značaj ranog prepoznavanja zlostavljanja kao i depresivne odnosno anksiozne simptomatologije kod mladih, u cilju kreiranja programa promocije mentalnog zdravlja i prevencije mentalnih poremećaja.

Ključne reči: studenti, depresivni simptomi, anksiozni simptomi, fizičko zlostavljanje, psihičko zlostavljanje. 


\section{INTRODUCTION}

From a socio-cultural point of view, an individual is a product of his/her social relationships and social life. An individual is also a member of certain social communities, whose principles and values he/she acquires while also gaining skills to participate in collective interactions. To accept the cultural characteristics of his/her community, an individual moves through a physical and psychological developmental process. The outcomes of all these integrated processes, which are under the influence of one's biological and psychological development, help an individual build his/her own identity and become an autonomous person (1). Mental disorders are one of the most important predictors of the development of disorders related to social health and the exclusion of individuals as functional members of society (2).

Both general and expert public discussion surround the concept of zero tolerance for violence, and special attention is given to the abuse of children, women and adolescents.

The abuse of young people includes the following: all forms of physical and/or emotional abuse, sexual abuse, neglectful or negligent treatment, and commercial or other forms of exploitation. All of these abuses lead to actual or potential harm to one's health. In Serbia, the data on the extent of harassment and abuse are still insufficient. Due to the lack of an integrated database and the difficulty of comparing results from different sectors, precise and complete data are still non-existent (3).

In approximately $80 \%$ of cases, the abusers are parents or guardians. The current literature on the topic states that potential risk factors are as follows: poverty, low levels of education and addiction (4). Predictors of psychological and physical abuse and harassment, which increase the risks for mental disorders, cannot be generalized to all cultural environments. In developed countries, the primary risk factors are divorce between parents, relationship with a stepfather or stepmother and parents' addictions. Studies conducted in multicultural environments, especially in North America, often include cultural and ethnic differences as risk factors, but the same cannot apply to predominantly ethnically homogenous countries such as Japan or China (5). The results of abuse and negligence can be divided into early (at an early age) or late (at an adult age) stages.

Mental health problems, which may occur as a consequence of abuse, can differ; they may start as changes in cognitive functioning (retardation, developmental disharmony, intellectual inhibition, difficulty with concentration) and psychological functioning (fear, anxiety, aggressiveness, anger, hostility, guilt, shame, changes in self-perception and self-destructive behaviour) and end up as mental disorders in adulthood such as depression and anxiety disorders, personality disorders, addictions and suicidal behaviour $(2,3,6)$.

Depression and anxiety typically have their first onset while an individual is of university age, making mental dis- orders a salient problem area for university students. From a public health perspective, the early detection of depression and anxiety is essential, especially in young adults, to implement appropriate screening and prevention programmes (6).

The aim of this study was to determine the prevalence of physical and psychological abuse and its correlation with depressive and anxiety symptoms among students.

\section{MATERIALS AND METHODS}

\section{Study design and participants}

The research we conducted used a cross-sectional survey of students attending the University of Kragujevac, Serbia, during a two-year period (2013-2015). The University of Kragujevac, with its twelve departmental faculties, is a state-owned university in Central Serbia. Six of its faculties are located in Kragujevac, while the other six faculties are located in five towns within Central Serbia, thus covering an area with more than 2,500,000 inhabitants. All twelve departmental faculties were selected for the survey: Faculty of Agronomy, Faculty of Economics, Faculty of Engineering, Faculty of Mechanical and Civil Engineering, Faculty of Medical Sciences, Faculty of Education, Faculty of Law, Faculty of Natural Sciences and Mathematics, Faculty of Technical Sciences, Teachers Training Faculty, Faculty of Philology and Arts, Faculty of Hotel Management and Tourism.

The sample for this cross-sectional survey comprised 1,940 randomly selected students from the total of 18,123 students at the University of Kragujevac. The students were randomly selected from every study year of each departmental faculty in proportion to the faculty's size and in relation to the total number of students at the university. The students were sorted using the university's student database according to a previously generated random order (random computer function).

Procedure: The Beck Depression Inventory (BDI-IA), the Beck Anxiety Inventory (BAI) and a self-administered anonymous questionnaire assessing social life characteristics and demographic and socioeconomic variables were used. Approval for the study was obtained from the Faculty of Medical Sciences Ethics Committee. Participation in the study was completely voluntary with no economic or other motivation. Informed consent was obtained, and confidentiality of the responses was assured. The study was conducted in the participants' own classrooms by the lead researcher. Those who were absent during the distribution of questionnaires were excluded.

Instruments: To determine the variables, a self-assessment questionnaire with detailed subdomain questions was used. The symptoms of depression were evaluated using the BDI-IA scale. This scale was developed in the 1960s and is one of the most widely used instruments for measuring the severity of depression, with a 
Table 1. Distribution of physical and psychological abuse in student population

\begin{tabular}{lcc}
\hline Variables & Total number & $(\%)$ \\
\hline Have you been physically harassed during the last six months? & $(\mathrm{N}=1857)$ & \\
Yes & 34 & 96.5 \\
No & 1792 & 1.7 \\
I don't remember & 31 & 17.4 \\
Have you been psychologically harassed during the last six months? & $(\mathrm{N}=1904)$ & 79.4 \\
Yes & 332 & 3.2 \\
No & 1513 & 59 \\
I don't remember & 59
\end{tabular}

focus on the behavioural and cognitive aspects of depressive disorders (7).

The questionnaire was designed to assess a variety of depressive symptoms that the individual may have experienced over the preceding week. It consisted of 21 items, with each response receiving a score on a scale ranging from 0 to 3 . The total score had a minimum of 0 and a maximum of 63. The internal consistency for the BDI-IA was good, with an average alpha coefficient of 0.81 for non-psychiatric samples and with highly inter-correlated items (8). The symptoms of anxiety were evaluated using the BAI scale, a short list that described 21 anxiety symptoms that were experienced over the preceding week. The scale consisted of 21 items with each response receiving a score on a scale ranging from 0 to 3 (9).

\section{Statistical analysis and assessment}

The data analysis was carried out using the IBM Statistical Package for the Social Sciences (SPSS) software version 19.0. Data cleaning was performed to detect any missing values, coding error or any illogical data values. The qualitative variables were presented as numbers and percentages. The continuous variables (scores on depression, anxiety and symptoms), were presented as the means and standard deviations (SD). The descriptive statistics for all the variables and the participants' depressive and anxiety symptoms were calculated and appropriately expressed as frequencies, mean values and standard deviations. A chi-squared test was used to find any existing associations between abuse characteristics and anxiety and depressive symptoms. All tests were 2-tailed, and the level of significance was set at $\mathrm{p}<0.05$.

\section{RESULTS}

Of the 1,968 distributed questionnaires, a total of 1,940 students completed the questionnaires, leading to a response rate of $98.6 \%$. The mean age of the participating students was 21.04 ( $\mathrm{SD}= \pm 2.23)$ years with a range of 18 57 years. The distribution of physical and psychological abuses of the sample is summarized in Table 1 .
This study revealed that the prevalence of depressive symptoms among physically abused students was $53.1 \%$, while the prevalence of anxiety symptoms was $47.6 \%$.

The prevalences of depressive and anxiety symptoms in psychologically abused students were $54.8 \%$ and $61.2 \%$, respectively.

Depressive symptoms were significantly related to physical $(\mathrm{p}<0.001)$ and psychological abuse $(\mathrm{p}<0.005)$. Anxiety symptoms were also significantly related to both physical $(\mathrm{p}=0.003)$ and psychological abuse $(\mathrm{p}<0.005)$.

The association between depressive and anxiety symptoms with potential risk factors are summarized in Table 2 .

\section{DISCUSSION}

The results of this study indicated that the prevalence of psychological abuse among the student population was $17.1 \%$, while the prevalence of physical abuse was $1.8 \%$.

Based on data from the Institute of Public Health of Serbia, approximately $6 \%$ of young people aged 15-29 were exposed to physical abuse at some point in their lives. Within this age group, males (8.7\%) were more exposed to physical violence compared to females (3.4\%). Exposure to physical violence decreased with age and was the highest in the 15-19 age group (8.0\%), while it was the lowest in the 20-29 age group (2.9\%). At the same time, $11.6 \%$ of young people aged $15-29$ were exposed to mental abuse. The highest percentage of people who were subjected to psychological violence was found in the 15-19 age group (12.9\%) and 20-24 age group $(12.5 \%)$, while it was significantly lower in the 25 29 age group (8.5\%) (2).

The prevalence of physical abuse in developed countries ranges from $4 \%$ to $16 \%$, while the prevalence of psychological abuse is approximately $10 \%(6)$.

The results of a national epidemiological survey conducted in the United States on a sample of 1,058 young people aged between 14 and 21 show that approximately $51 \%$ of females and $43 \%$ of males have survived at least one of the three types of abuse (physical, psychological or sexual) (10). 


\begin{tabular}{|c|c|c|c|c|c|c|}
\hline \multicolumn{7}{|c|}{ Depressive symptoms } \\
\hline Variable & Non & Mild & $\begin{array}{l}\text { Moderate } \\
\text { \& severe }\end{array}$ & $x^{2}$ & Df & $\mathrm{P}$ \\
\hline \multicolumn{7}{|c|}{$\begin{array}{l}\text { Have you been physically } \\
\text { harassed during the last six } \\
\text { months? }\end{array}$} \\
\hline Yes & $46.9 \%$ & $28.1 \%$ & $25.0 \%$ & 19.943 & 4 & $<0.001$ \\
\hline No & $73.4 \%$ & $17.8 \%$ & $8.7 \%$ & & & \\
\hline \multicolumn{7}{|c|}{$\begin{array}{l}\text { Have you been psychologi- } \\
\text { cally harassed during last six } \\
\text { months? }\end{array}$} \\
\hline Yes & $52.5 \%$ & $26.6 \%$ & $21.0 \%$ & 139.130 & 6 & $<0.005$ \\
\hline No & $81.8 \%$ & $12.8 \%$ & $5.4 \%$ & & & \\
\hline \multicolumn{7}{|c|}{ Anxiety symptoms } \\
\hline \multicolumn{7}{|c|}{$\begin{array}{l}\text { Have you been physically } \\
\text { harassed during the last six } \\
\text { months? }\end{array}$} \\
\hline Yes & $45.2 \%$ & $25.8 \%$ & $29.0 \%$ & 16.323 & 4 & $<0.003$ \\
\hline No & $67.6 \%$ & $22.4 \%$ & $9.9 \%$ & & & \\
\hline \multicolumn{7}{|c|}{$\begin{array}{l}\text { Have you been psychologi- } \\
\text { cally harassed during last six } \\
\text { months? }\end{array}$} \\
\hline Yes & $38.9 \%$ & $29.1 \%$ & $32.1 \%$ & 198.524 & 6 & $<0.005$ \\
\hline No & $32.1 \%$ & $6.5 \%$ & $8.3 \%$ & & & \\
\hline
\end{tabular}

"Bold values show and emphasis the significance of the factors

Al-Fayez and colleagues conducted research on a sample of 4,467 high school students and determined that $18 \%$ of young people were abused by a mother, $15 \%$ by a father and $18 \%$ by a third-party person during the previous six months. For the time period of the past 12 months, the values were $4.3 \%, 5.8 \%$, and $6.4 \%$, respectively. The values obtained for lifetime experiences of these abuses were $3.4 \%, 5.3 \%$ and $5.8 \%$, respectively. The authors found that child abuse was closely associated with parental divorce, high scores for anxiety/depression, difficulty studying and difficulty establishing social relationships. It was also found that psychological abuse by a mother was the most important predictor of depression, anxiety and low self-esteem (11.5-19.7\% of variance) (11).

The present study showed that physical and psychological abuse were significantly associated with depressive and anxiety symptoms. More than one-quarter of the respondents were physically abused (28.1\%), and more than one-third of those who were psychologically abused had mild depressive symptoms (26.6\%).

This study assessed the association between physical and psychological abuse and anxiety symptoms. A little less than one-third of students who were psychologically abused (25.8\%) and about one-third of students (29.1\%) who were physically abused manifest mild anxiety symptoms.
Similar to our results, the results of other studies have also shown a correlation between various types of violence and psychological distress, depression (12-15), anxiety (16$20)$, and depression and anxiety (5, 21-23).

Norman and colleagues indicated that physically abused individuals are at higher risk of depressive disorders (54\%) and anxiety disorders (especially panic and post- traumatic stress disorder) (51\%) (4).

Some studies have reported that individuals who were physically abused during childhood have a 1.5 higher likelihood of suffering from mental disorders later on in life (24). More precisely, Gal and colleagues indicated that physical abuse in early life stages increases the risk of anxiety disorders in adolescence. This claim was confirmed by a study conducted in Israel with a sample of 4,589 adolescents (19). It is widely understood that physical abuse is almost always associated with other types of violence. Young people are often exposed to different types of violence. Adolescents who have experienced more than one type of harassment (physical, psychological, sexual) more commonly have mental health problems (i.e., depression, anxiety and behaviour disorders) (5). This finding is consistent with the results shown in this study. 
The culmination of enduring violence, in addition to consequent mental disorders, often trigger suicide attempts. Skapinakis et al. state that victims of harassment have suicidal thoughts more often, especially if violence happens once a week or more (25). The most essential step in violence prevention is directed toward the general population. Achieving zero tolerance of violence requires breaking taboos about family violence, destigmatizing abused individuals and employing active multidisciplinary processes that coordinate legal and executive activities with the maximum involvement of institutions and individuals.

Healthcare systems have a unique role in these activities and require training on the specific procedures for identifying abused and harassed individuals and helping them access adequate treatment. Depression and anxiety in younger populations can be integral to the development of multiple symptoms and can arise as a consequence of reactivating early childhood traumas, such as forms of violence (6).

The primary limitation of the study was its cross-sectional design, which did not permit inferences about possible causal relations between the explanatory variables and the disorders of interest. Moreover, as the survey was completed anonymously, it was not possible to assess the testretest reliability of the BDI/BAI in this sample. Another limitation was the self-reported nature of this study. Finally, our sample comprised a group of students from one university in Serbia, which limited the ability to generalize the results to other universities. According to Strategy 2020 by the World Health Organization strengthening mental health promotion programmes is highly relevant $(26,27)$.

\section{CONCLUSION}

These results demonstrate that the high rates of depressive and anxiety symptoms among university students are related to physical and psychological abuse. The past several years have provided data that highlight this neglected public health problem in institutes of higher education.

The importance of early identification, especially of the minor signs of depression, could prevent or reduce its severity and chronicity. From a public health perspective, the onset and development of mental illness in students is a potentially critical area for intervention programmes. A particular challenge is to promote the early diagnosis of depression by initiating community-based intervention programmes and to reduce the stigma of mood disorders. Such efforts hold substantial promise for the development of interventions that may have a positive impact on the health and well-being of university students.

\section{ACKNOWLEDGEMENTS}

This work was supported by the Faculty of Medical Sciences, University of Kragujevac, (Junior Project 13-12).

\section{CONFLICT OF INTEREST}

The authors fully declare that there is no conflict of interest that could be perceived as prejudicing the impartiality of the research described.

\section{REFERENCES}

1. Araya A, Lewis G, Rojas G, Fritsch R. Education and income: which is more important for mental health? J Epidemiol Community Health 2003; 57:501-5

2. Knežević K, Simić D, Ivanović I. Zdravlje mladih u Republici Srbiji. Finalni izveštaj Beograd: Institut za javno zdravlje Srbije "Dr Milan Jovanović Batut”, 2009.

3. Mitković M. Zlostavljanje u detinjstvu i adolescenciji kao faktor rizika za povećanu sklonost odrasle osobe ka zlostavljanje dece. Beograd: Ministarstvo rada i socijalne politike, 2009.

4. Norman RE, Byambaa M, De R, Butchart A, Scott J, Vos T. The Long-Term Health Consequences of Child Physical Abuse, Emotional Abuse, and Neglect: A Systematic Review and Meta-Analysis. Plos Med 2012;9(11):e1001349.

5. Nguyen HT, Dunne MP, Le AV. Multiple types of child maltreatment and adolescent mental health in Viet Nam. Bull World Health Organ 2010;88(1):22-30.

6. Simic Vukomanovic I. Assessment of mental health and prevention of mental disorders among University students (disertation). Kragujevac: Faculty of Medical sciences University of Kragujevac, 2016.

7. Beck AT, Steer RA. Manual for the Beck Depression Inventory. San Antonio, TX: Psychological Corporation; 1993.

8. Ignjatović-Ristić D, Hinić D, Jović J. Evaluation of the Beck Depression Inventory in a nonclinical student sample. West Indian Med J 2012; 61(5): 489-93.

9. Beck AT, Steer RA. Beck Anxiety Inventory (BAI) Manual. Oxford (UK): Pearson; 1990

10. Ybarra ML, Espelage DL, Langhinrichsen-Rohling J, Korchmaros JD, Boyd D. Lifetime Prevalence Rates and Overlap of Physical, Psychological, and Sexual Dating Abuse Perpetration and Victimization in a National Sample of Youth. Arch Sex Behav 2016;45(5):1083-99.

11. Al-Fayez GA1, Ohaeri JU, Gado OM. Prevalence of physical, psychological, and sexual abuse among a nationwide sample of Arab high school students: association with family characteristics, anxiety, depression, self-esteem, and quality of life. Soc Psychiatry Psychiatr Epidemiol 2012;47(1):53-66.

12. Jewkes RK, Dunkle K, Nduna M, Jama PN, Puren A. Associations between childhood adversity and depression, substance abuse and HIV and HSV2 incident infections in rural South African youth. Child Abuse Negl 2010;34: 833-41.

13. Fergusson D, Boden J, Horwood L. Exposure to childhood sexual and physical abuse and adjustment in early adulthood. Child Abuse Negl 2008;32:607-19. 
14. Bonomi AE, Cannon EA, Anderson ML, Rivara FP, Thompson RS. Association between self-reported health and physical and/or sexual abuse experienced before age 18. Child Abuse Negl 2008; 32: 693-701.

15. Courtney EA, Kushwaha M, Johnson JG. Childhood emotional abuse and risk for hopelessness and depressive symptoms during adolescence. J Emot Abuse 2008;8(3):281-98.

16. Afifi TO, Enns MW, Cox BJ, Asmundson GJG, Stein $\mathrm{MB}$, et al. Population attributable fractions of psychiatric disorders and suicide ideation and attempts associated with adverse childhood experiences. Am J Public Health 2008; 98:946-52.

17. Cougle JR, Timpano KR, Sachs-Ericsson N, Keough ME, Riccardi CJ. Examining the unique relationships between anxiety disorders and childhood physical and sexual abuse in the National Comorbidity Survey-Replication. Psychiatry Res 2010;177:150-5.

18. Fujiwara T, Kawakami N. Association of childhood adversities with the first onset of mental disorders in Japan Results from the World Mental Health Japan, 2002-2004. J Psychiatr Res 2011;45(4):481-7.

19. Gal G, Levav I, Gross R. Psychopathology among adults abused during childhood or adolescence: results from the Israel-based World Mental Health Survey. J Nerv Ment Dis 2011;199:222-9.

20. Green JG, McLaughlin KA, Berglund PA, Gruber MJ, Sampson NA, et al. Childhood adversities and adult psychiatric disorders in the national comorbidity sur- vey replication I: associations with first onset of DSMIV disorders. Arch Gen Psychiatry 2010;67: 113-23.

21. Hovens JG, Wiersma JE, Giltay EJ, van Oppen P, Spinhoven P, Penninx BW, et al. Childhood life events and childhood trauma in adult patients with depressive, anxiety and comorbid disorders vs. controls. Acta Psychiatr Scand 2010;122(1):66-74.

22. Afifi TO, Brownridge DA, Cox BJ, Sareen J. Physical punishment, childhood abuse and psychiatric disorders. Child Abuse Negl 2006;30(10):1093-103.

23. Afifi TO, Mota NP, Dasiewicz P, MacMillan HL, Sareen J. Physical punishment and mental disorders: results from a nationally representative US sample. Pediatrics 2012; 130(2): 184-92.

24. Fergusson DM, Boden JM, Horwood LJ. Exposure to childhood sexual and physical abuse and adjustment in early adulthood. Child Abuse Negl. 2008;32(6):607-19.

25. Skapinakis P, Bellos S, Gkatsa T, Magklara K, Lewis G, Araya $R$, et al. The association between bullying and early stages of suicidal ideation in late adolescents in Greece. BMC Psychiatry 2011;11:22.

26. World Health Organization. Health 2020: A European policy framework and strategy for the 21 st century. Copenhagen (DK): World Health Organization; 2013.

27. Simic Vukomanovic I, Mihajlovic G, Kocic S, Đonovic N, Bankovic D, Vukomanovic V, Dukic Dejanovic S. The prevalence and socioeconomic correlates of depressive and anxiety symptoms among group of 1940 Serbian University students. Vojnosanit Pregl 2016; 73(2): 169-77 